
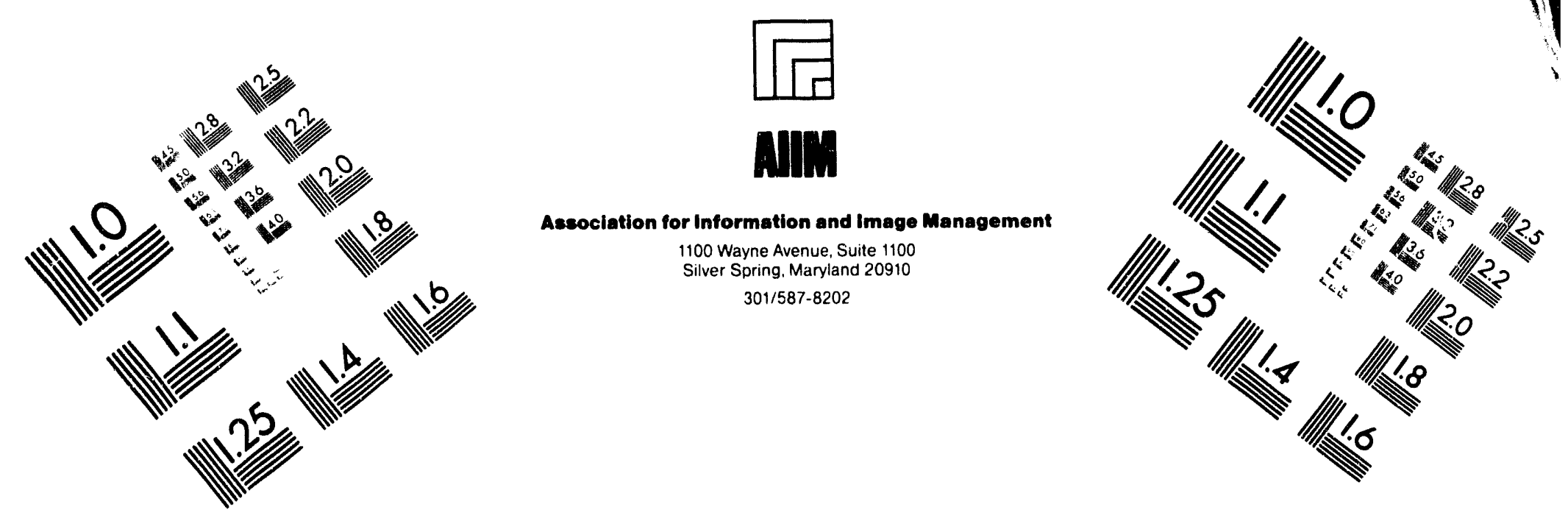

\title{
Centimeter
}

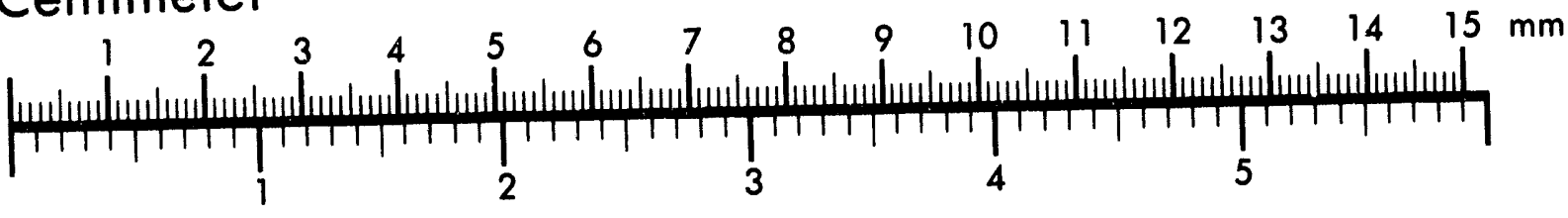
Inches
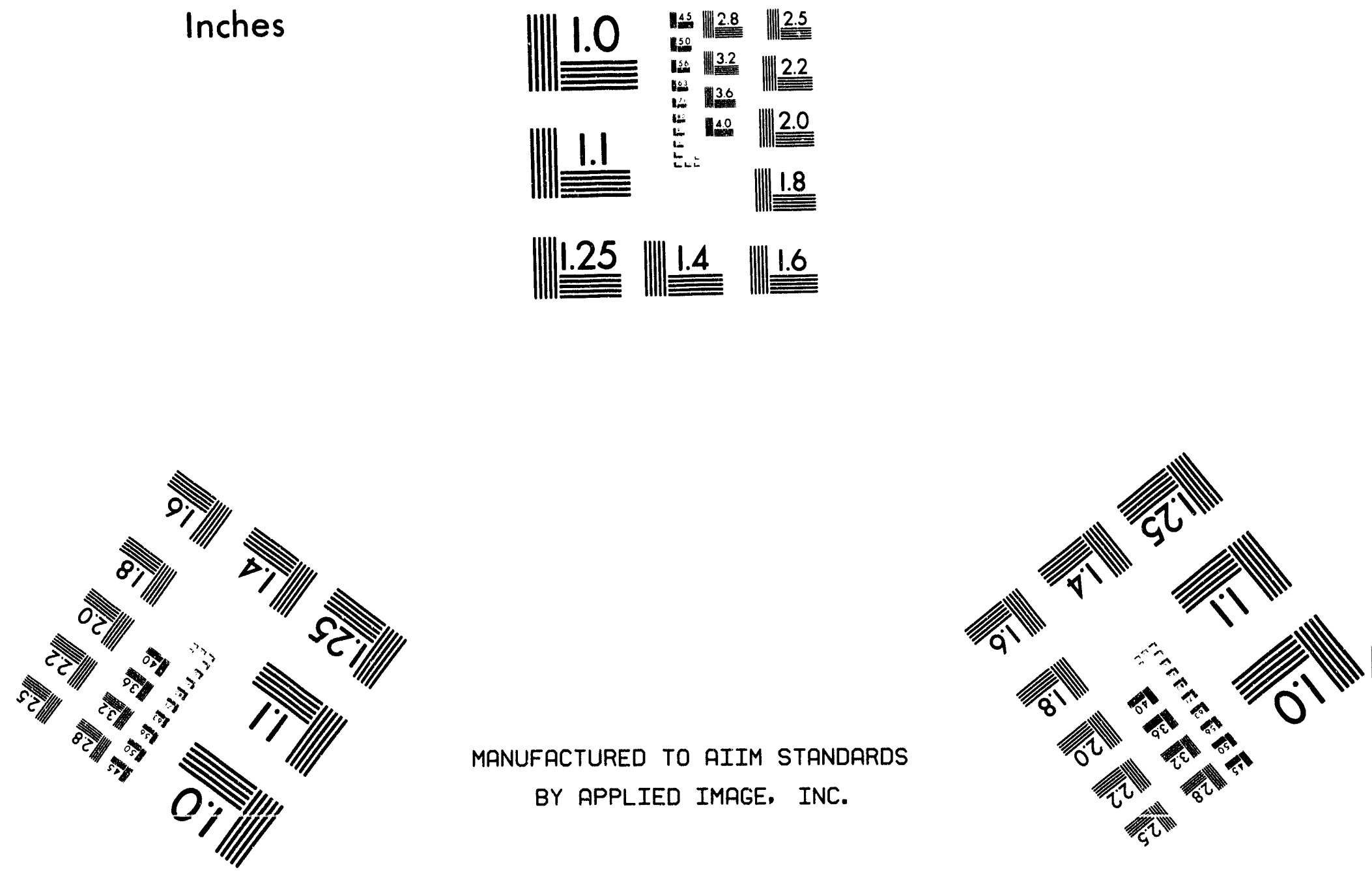

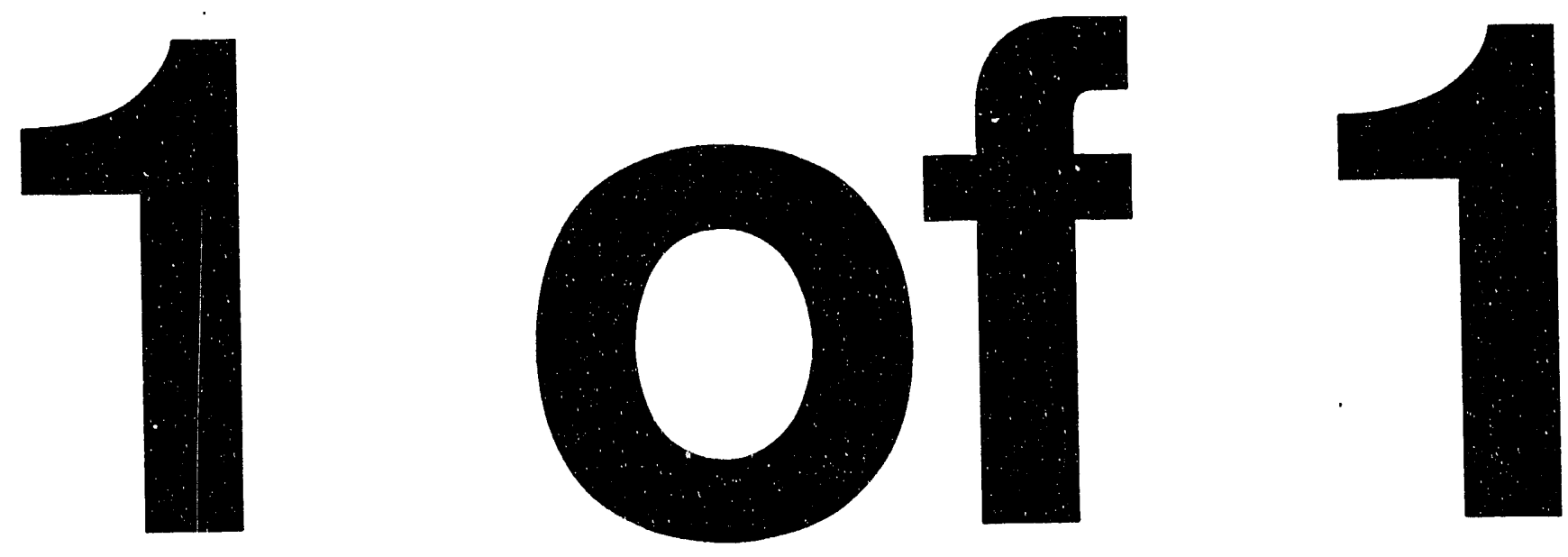


\section{BIOLOGICAL PROCESSES IN THE WATER COLUMN \\ OF THE SOUTH ATLANTIC BIGHT: \\ ZOO PLANKTON RESPONSES}

Final Report

Gustav-Adolf Paffenhisfer

skidway Institute of Oceanography P.O. Box 13687 Savannah, GA 31416

September 25, 1992

PREPARED FOR THE

U.S. DEPARTMENT OF ENERGY

UNDER CONTRACT DE-FG09-85-ER60354

$$
\text { Magren }
$$




\section{Table of Contents}

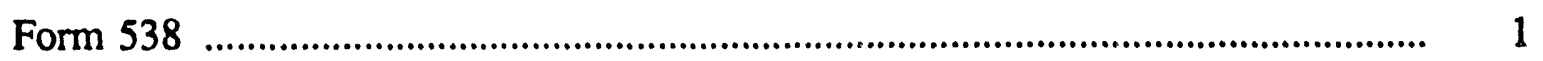

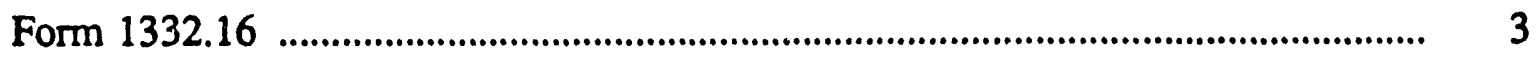

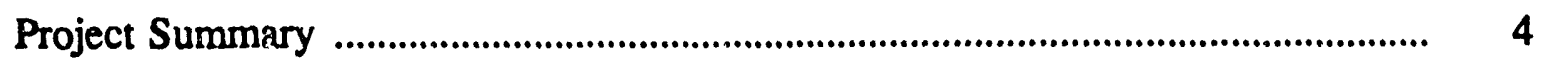

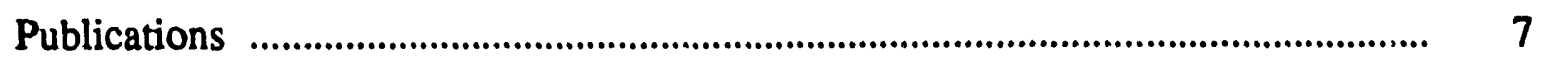

Manuscripts in Press or Accepted .................................................................. 9

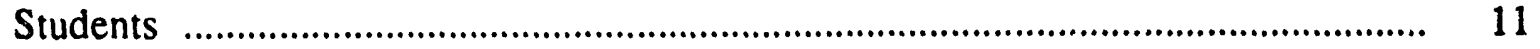




\section{UNIVERSITY CONTRACTOR, GRANTEE, AND COOPERATIVE AGREEMENT RECOMMENDATIONS FOR ANNOUNCEMENT AND DISTRIBUTION OF DOCUMENTS}

See Instructions on Reverse Side

\begin{tabular}{l|l}
\hline 1. DOE Roport No. & $\begin{array}{l}\text { 3. Title Biological Processes in the Water Column } \\
\text { of the South Atlantic Bight: Zooplankton } \\
\text { Responses }\end{array}$ \\
\hline $\begin{array}{l}\text { 2. DOE Coniroct No. } \\
\text { DE-FG09-85ER60354 }\end{array}$ & \\
\hline
\end{tabular}

4. Type of Document (" $x$ " one)

A. Scientific and wechnical repor

口b. Conference paper:

Title of conference

Date of conference

Exact location of conference

Sponsoring organization

Dc. Other (Specify)

5. Recommended Announcement end Distribution (" $x$ " one)

*a. Unrestricted unlimitod distribution.

Db. Make available only within DOE and to DOE contractors and other U. S. Government agencies and their contractors.

Dc. Other (Specify)

6. Aeeson for Recommended Restrictions

7. Patent and Copyright Information:

Does this information product disclose any new equipment, process, or material? $\square$ No $\square$ Yes If so, identify page nos.

Hes an invention disclosure been submitted to DOE covering any aspect of this information product? $\square$ No $\square$ Yes

If so, identify the DOE (or other) disclosure number and to whom the disclosure was submitted.

Are there any patent-related objections to the release of this information product? $\square$ No $D Y_{e}$ If so, state these objections.

Does this information product contain copyrighted material? $\square$ No $\square$ Yes

If so, identify the page numbers. and attach the license or other authority for the government to reproduce.

B. Submitted by Name and Position (Please print or type)

G. -A. Paffenhöfer, Professor

Organization

Skidaway Institute of Oceanography

\begin{tabular}{l|l|l}
\hline Signature & Pate \\
Y. P. P. & $912 / 598-2489$ & September 1992 \\
\hline
\end{tabular}

FOR DOE DR OTHER AUTHORIZED

USE ONLY

9. Patent Clearance (" $x$ " one)

Q8. DOE patent clearance hes been granted by responsible DOE patont group.

$\square_{b}$. Report hes been sent to responsible DOE patent group for clearance. 


\section{PROJECT SUMMARY}

The main goal of our research was to determine and understand the major processes governing the abundance, distribution, composition and eventual fate of zooplankton on the southeastern shelf of the U.S. in relation to water circulation. Over much of the shelf circulation is dominated by the Gulf Stream and/or atmospheric forcing. Most of our studies concentrated on processes on the middle and outer shelf. On the latter, pronounced biologicai production occurs year-round at frequent intervals and is due to Gulf Stream eddies which move by at an average frequency of one every week. These eddies are rich in nutrients which, when upwelled into the euphotic zone, lead to pronounced primary production which then triggers zooplankton production.

During summer when shelf waters become less dense upwelled Gulf Stream water can intrude onto the continental shelf if the following conditions occur simultaneously: a frontal eddy passing at the shelf break, the Gulf Stream being close to the shelf break, and wind suress being north-to-eastward. If these conditions prevail for more than one week most of the continental shelf can be flooded by upwelled water, sometimes covering in excess of $10,000 \mathrm{~km}^{2}$, on occasion reaching the shore. Depending on the species, concentration and spatial extent of seed populations of phyto- and zooplankton, these can develop into blooms usually resulting in exhaustion of nutrients by phytoplankton within 2 weeks, much of the phytoplankton being consumed by developing zooplankton populations which are either smaller copepods or rapidly growing tunicates. Copepod populations can increase as rapidly as $9 \%$ per day, and tunicates (salps) as fast as $50 \%$ per day, the latter being able to outgrow and contain developing phytoplankton populations. Only large phytoplankton cells remain 
ungrazed and can continue to exist in dense patches. The longer intruded Gulf Stream - water remains on the middle to inner shelf the higher the probability of the phytoplankton being consumed by zooplankton. Longer residence times of mid shelf water are observed during summer because of weak winds and only intermittent effects of the Gulf Stream. Therefore, the probability is high that most of the primary production is consumed or decomposed, and part of the herbivorous-omnivorous zooplankton is consumed by carnivores including vertebrates before this water leaves the inner and middle part of the continental shelf.

During winter, the water on the continental shelf is of higher density (cooler), not permitting nutrient-rich, upwelled water to advance far shoreward, usually not advancing farther shoreward than the $30 \mathrm{~m}$ isobath. On- or offshore displacement of water is mainly due to intermittently occurring atmospheric forcing supported by Gulf Stream forcing at the shelf break. Gulf Stream eddies, or part of them, are repeatedly displaced onto the outer, and occasionally middle shelf; they are characterized by developing or advanced phytoplankton blooms, and quite often by tunicates which, like in summer, have the potential to consume much, if not most of that primary production. This implies, that even during winter, not only considerably high primary but also secondary (zooplankton) production is observed on the middle and outer shelf. Temperatures in these productive waters usually exceed $16^{\circ} \mathrm{C}$. Residence times of water on the shelf are shorter than in summer which implies that, unless tunicates prevail much of the primary production leaves the shelf without being consumed. Thus, export of organic matter from the shelf can be pronounced.

During spring, meteorological conditions strongly affect processes of the middle 


$$
-6-
$$

and inner shelf waters. Direction and strength of wind stress as well as periods of unidirectional forcing largely determine the extent of water displacement. Strong forcing and extended periods of wind stress towards offshore, in conjunction with pronounced runoff, can result in displacement of inshore water to the outer shelf, displacing at the same time offshore water of higher density towards shore. Weaker forcing with short periods of wind forcing in one direction increases the residence time of water in each respective shelf region and does not allow for much cross-shelf exchange. Secondary production under the first regime appears to be much more pronounced than under the second one.

These observations were only possible because of the interdisciplinary nature of DOE's Southeastern Continental Shelf Program, and the fact that virtually all participants shared shiptime and data and contributed to manuscripts in a truly cooperative manner.

A list of publications and manuscripts in press/accepted for publication, and of talks acknowledging DOE grants follows. 


\section{Publications and Talks which Acknowledge DOE Grant DE-FG09-85ER60354}

\section{Publications:}

1978 Atkinson, L.P., G.-A. Paffenhöfer and W.M. Dunstan. The chemical and biological effect of a Gulf Stream intrusion off St. Augustine, Florida. Bull. Mar. Sci. 28(4):667-679.

1979 Paffenhöfer, G.-A. and S.C. Knowles. Ecological implications of fecal pellet size, production, and consumption by copepods. J. Mar. Res. 37:35-49.

1980 Paffenhöfer, G.-A., D. Deibel, L.P. Atkinson, and W.M. Dunstan. The relation of concentration and size distribution of suspended particulate matter to hydrography in Onslow Bay, North Carolina. Deep-Sea Res. 27:435-448.

1980 Paffenhöfer, G.-A. Zooplankton distribution as related to summer hydrographic conditions in Onslow Bay, North Carolina. Bull. Mar. Sci. 30:819-832.

1980 Bishop, S.S., J.A. Yoder, and G.-A. Paffenhöfer. Phytoplankton and nutrient variability along a cross-shelf transect off Savannah. Est. Coast. Mar. Sci. 11:359-368.

1981 Hofmann, E.E., J.M. Klinck and G.-A. Paffenhöfer. Concentrations and vertical fluxes of fecal pellets on a continental shelf. Mar. Biol. 62:327335.

1981 Yoder, J.A., L.P. Atkinson, J.O. Blanton, D.R. Deibel, D.W. Menzel and G.-A. Paffenhöfer. Plankton dynamics of the southeastern shelf. Science 214:352-353.

1982 Gardner, W.S. and G.-A. Paffenhöfer. Nitrogen regeneration by the subtropical marine copepod Eucalanus pileatus. J. Plankton Res. 4:725-734.

1983 Paffenhöfer, G.-A. Vertical zooplankton distribution on the northeastern Florida shelf and its relation to temperature and food abundances. J. Plankton. Res. 5:15-33.

1984 Paffenhöfer, G.-A., and W.S. Gardner. Ammonium release by juveniles and adult females of the subtropical marine copepod Eucalanus pileatus? J. Plankton Res. 6:505-513. 
Publications, continued:

1984 Paffenhöfer, G.-A.. Calanoid copepod feeding: Grazing on small and large particles. Pages 75-95 In: D.G. Meyers and J.R. Strickler (eds.) Trophic Interactions Within Aquatic Ecosystems, AAAS Selected Symposium 85. Westview Press, Boulder, Colorado.

1984 Paffenhöfer, G.-A., B.T. Wester and W.D. Nicholas. Zooplankton abundance in relation to state and type of intrusion on the southeastern United States shelf during summer. J. Mar. Res. 42:995-1017.

1984 Atkinson, L.P., P.G. O'Malley, J.A. Yoder and G.-A. Paffenhöfer. The effect of summertime shelfbreak upwelling on nutrient flux in southeastern United States continental shelf water. J. Mar. Res. 42:969-993.

1985 Paffenhöfer, G.-A. The abundance and distribution of zooplankton on the southeastern shelf of the United States. Pages 104-117 In: L.P. Atkinson, D.W. Menzel and K.A. Bush (eds.), Oceanography of the Southeastern U.S. Continental Shelf. AGU, Washington, DC.

1985 Paffenhöfer, G.-A. and K.B. Van Sant. The feeding response of a marine planktonic copepod to quantity and quality of particles. Mar. Ecol. Progr. Ser. 27:55-65.

1986 Paffenhöfer, G.-A. and J.D. Orcutt, Jr. Feeding, growth and food conversion of the marine cladoceran Penilia avirostris. J. Plankton Res. 8:741754.

1987 Paffenhöfer, G.-A. and T.N. Lee. Development and persistence of patches of thaliacea. South African Journal of Marine Science 5:305-318.

1987 Paffenhöfer, G.-A., L.P. Atkinson, J.O. Blanton, T.N. Lee, L.R. Pomeroy and J.A. Yoder. Summer upwelling on the southeastern continental shelf of the U.S.A. during 1981: Introduction. Prog. Oceanogr. 19:221-230.

1987 Atkinson, L.P., T.N. Lee, J.O. Blanton and G.-A. Paffenhöfer. Summer upwelling on the southeastern continental shelf of the U.S.A. during 1981: Hydrographic observations. Prog. Oceanogr. 19:231-266.

1987 Paffenhöfer, G.-A. and T.N. Lee. Summer upwelling on the southeastern continental shelf of the U.S.A. during 1981: Distribution and abundance of particulate matter. Prog. Oceanogr. 19:373-401. 
Publications, continued:

1987 Paffenhöfer, G.-A., B.K. Sherman and T.N. Lee. Summer upwelling on the southeastern continental shelf of the U.S.A. during 1981: Abundance, distribution and patch formation of zooplankton. Prog. Oceanogr. 19:403-436.

1987 Paffenhöfer, G.-A., L.P. Atkinson, J.O. Blanton, T.N. Lee, L.R. Pomeroy and J.A. Yoder. Summer upwelling on the southeastern continental shelf of the U.S.A. during 1981: Summary and conclusions. Prog. Oceanogr. 19:437-441.

1987 Pomeroy, L.R., G.-A. Paffenhöfer and J.A. Yoder. Summer upwelling on the southeastern continental shelf of the U.S.A. during 1981: Interaction of phytoplankton, zooplankton and microorganisms. Prog. Oceanogr. 19:353372.

1988 Paffenhöfer, G.-A. and D.E. Stearns. Why is Acartia tonsa (Copepoda: Calanoida) restricted to nearshore environments? Mar. Ecol. Prog. Ser. 42:33-38.

1991 Paffenhöfer, G.-A. Some characteristics of abundant subtropical copepods in estuarine, shelf and oceanic waters. Bull. Plankton Soc. Japan, Special Volume: 201-216.

In Press:

Paffenhöfer, G.-A., L.P. Atkinson, T.N. Lee, J.O. Blanton, B.K. Sherman and T.B. Stewart. Variability of particulate matter and abundant zooplankton of the southeastern U.S. during Spring of 1984 and 1985. Continental Shelf Research.

Pomeroy, L.R., J.O. Blanton, G.-A. Paffenhöfer, K.L. von Damm, P.G. Verity and H.L. Windom. Chapter 2: Inner Shelf Processes. In: Menzel, D.W., ed., "Ocean Processes: U.S. Southeast Continental Shelf,"f Washington, DC, U.S. Department of Energy.

Verity, P.G., T.N. Lee, J.A. Yoder, G.-A. Paffenhöfer, J.O. Blanton and C.R. Alexander. Chapter 3: Outer Shelf Processes. In: Menzel, D.W., ed., "Ocean Processes: U.S. Southeast Continental Shelf,"f Washington, DC, U.S. Department of Energy. 
Talks:

G.-A. Paffenhöfer, B.K. Sherman and J.A. Odell. Biological developments in summer upwellings on the southern shelf. American Geophysical Union, Fall Meeting, San Francisco, CA, 7-15 December 1982.

G.-A. Paffenhöfer and K.B. Van Sant. Feeding of the marine plantonic copepod Eucalanus pileatus on living and non-living material. AGU Ocean Sciences Meeting, New Orleans, LA, 23-27 January 1984.

G.-A. Paffenhöfer, B.K. Sherman and J.A. Odell. Zooplankton developments in upwelled water masses on the U.S. southeastern shelf. AGU Fall Meeting, San Francisco, CA, 3-7 December 1984.

G.-A. Paffenhöfer, B.K. Sherman and T.N. Lee. Development and persistence of zooplankton patches during summer on the southeastern shelf of the U.S.A. AGU Ocean Sciences Meeting, New Orleans, LA, 13-17 January 1986.

G.-A. Paffenhöfer and T.N. Lee. Development and persistence of patches of thaliacea. International Symposium on Population and Community Ecology in the Benguela Upwelling Region and Comparable Frontal Systems, Cape Town, South Africa, 8 to 12 September 1986.

G.-A. Paffenhöfer, J.O. Blanton and L.-Y. Oey. Positive and negative effects of physical forcing on recruitment in the pelagic environment. AGU Fall Meeting, San Francisco, CA, 8 to 12 December 1986.

G.-A. Paffenhöfer. Characteristics of abundant subtropical copepods in estuarine, shelf and oceanic waters. AGU Fall Meeting, San Francisco, CA, 6 to 11 December 1988.

G.-A. Paffenhöfer. Marine cyclopoid copepods: Some considerations on their ubiquitous abundance. American Society of Limnology and Oceangoraphy, Annual Meeting, Williamsburg, VA, 10-15 June 1990.

G.-A. Paffenhöfer, L.P. Atkinson, L.R. Bulluck and P.G. Verity. Control of planktonic copepods by gelatinous zooplankton. ASLO Annual Meeting, Halifax, Nova Scotia, 10 to 14 June 1991.

G.-A. Paffenhöfer. Zooplankton processes in neritic regions. International Symposium - Benguela Trophic Functioning, Cape Town, South Africa, 8 to 13 September 1991. 


\section{GRADUATE STUDENTS SUPPORTED BY DOE}

Don Deibel, graduated 1979, Ph.D. degree in Ecology, University of Georgia, thesis title: "Laboratory and field studies on the feeding, growth and swarm dynamics of neritic tunicates from the Georgia Bight."

Holly J. Price, graduated 1985, Ph.D. degree in Ecology, University of Georgia, thesis title: "Cinematographic analyses of the feeding behavior of marine calanoid copepods."

Marie H. Bundy, will graduate in 1993, Ph.D. degree in Ecology, thesis title: "Functional morphology, feeding and swimming behavior of the genus Centropages (Copepoda, Calanoida)" 

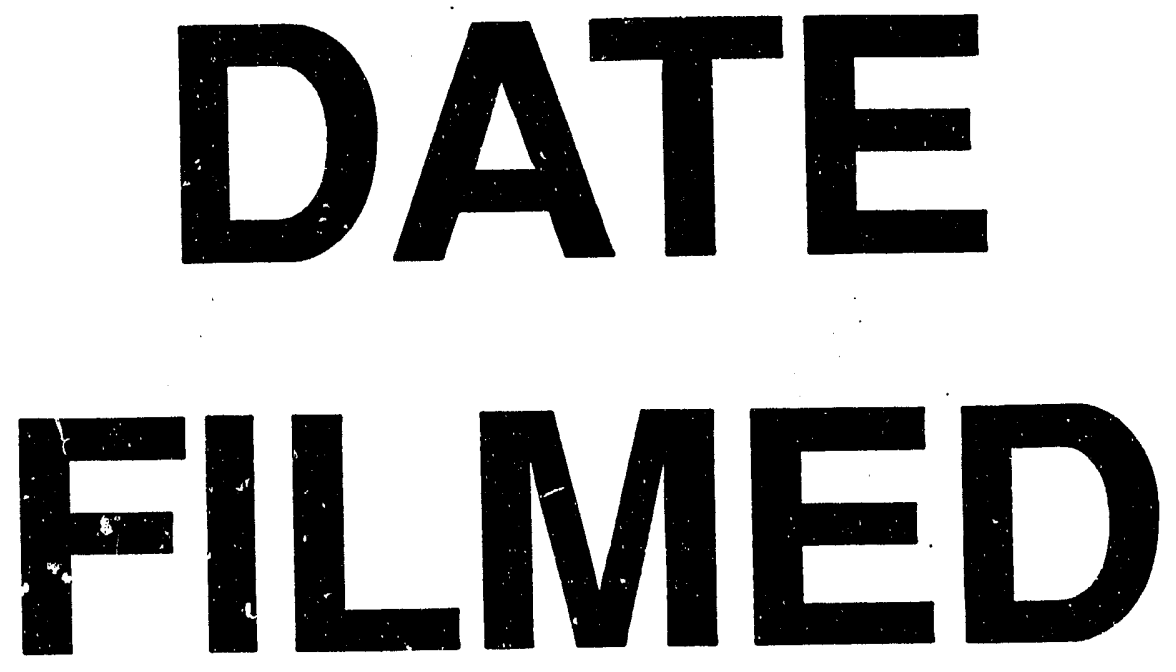

$8 / 18 / 93$
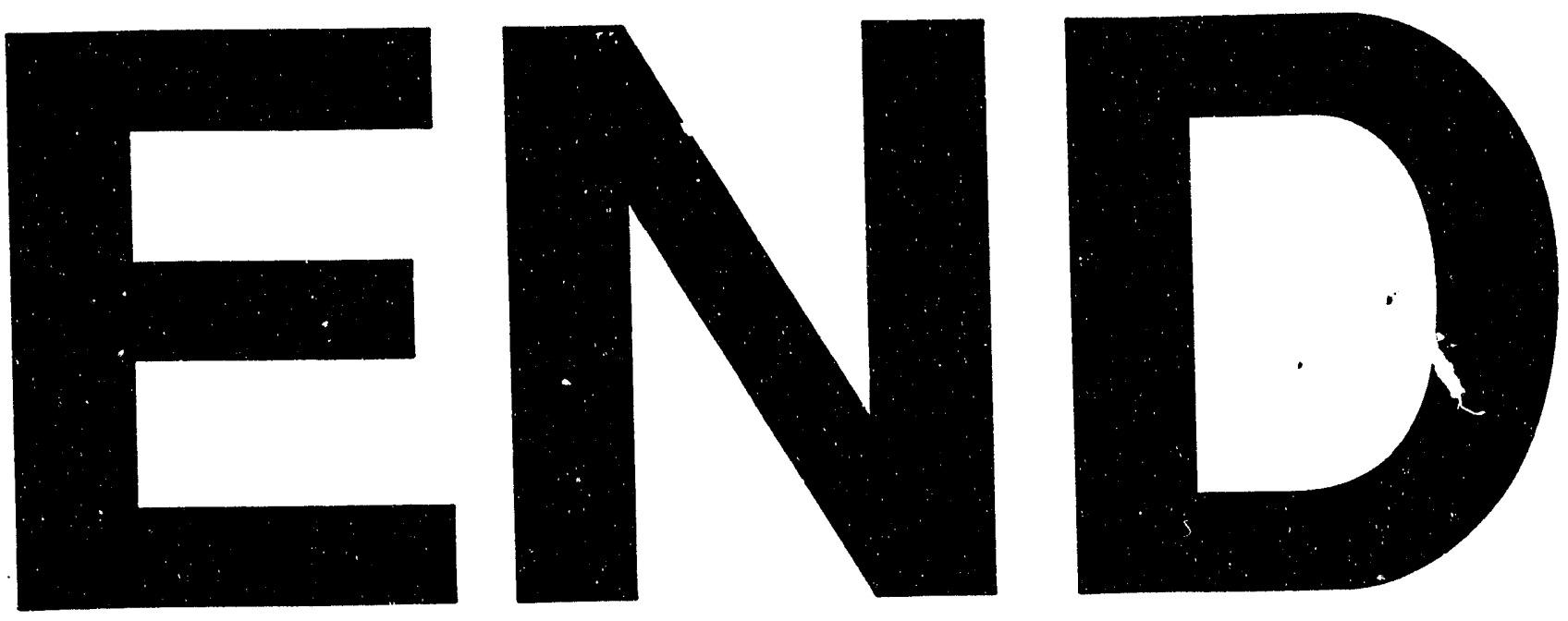
